\title{
Testmagasság és kogníció a munkában ${ }^{1}$
}

\author{
LIBICKI ÉVA ${ }^{2}$
}

Több kutatás bizonyította már (lásd később), hogy a felnőttkori testmagasság a munkabírás jelképe, amit a fizikai munka piacán előszeretettel díjaznak és részesítenek előnyben. Helyettesítheti az értelmi képességeket, vagy egyéb emberi tulajdonságokat, mint pl. az iskolai végzettséget. Mi több, a magasság és a jó egészségi állapot a munkaadók számára azt jelképezheti, hogy a munkavállaló megfelelő családi háttérrel bír, vagyis számára minden adott, hogy kiváló munkaképességekkel rendelkezzen. A magasság tehát a munkáltató számára meghatározó tulajdonsága a dolgozónak és a munkavégzés várható minőségének.

A tanulmány tizenkét longitudinális felmérés eredményeit mutatja be, amelyeket Indonéziában, a Közép-Jáva vidéki régiókban végeztek. Ennek során vizsgálták a képzettséget, az értelmi képességek és az egészségi állapot indikátorait, a családi hátteret, a munkahely szektorát és a foglalkozás jellemzőit, s megállapították, hogy a magasság összefügg az órabérrel: a magasságért járó többletbér összege viszonylag magas mind a bérmunkások, mind az egyéni vállalkozók körében. Mivel a felnőttkori magasság főként az első néhány életévben alakul ki, ezért a cikk írói arra a következtetésre jutottak, hogy az ebben a kritikus időszakban ért hatások maradandó következményekkel bírnak a munkaerőpiaci termelékenységre.

\section{Az emberi tőke és a munkaerőpiaci teljesítmény}

Bőséges bizonyíték szolgál arra vonatkozóan, hogy a magasabb emberek tovább élnek, egészségesebbek, képzettebbek és magasabb színvonalon élnek, mint az átlag (Deaton and Arora 2009, Fogel 2012, Strauss - Thomas 1998). Noha a felnőttkori magasságot főként a kora gyermekkori viszonyok (a táplálkozás, a betegségek, a terhesség alatti egészségi állapot javítására irányuló erőfeszítések és az első néhány életév történései) határozzák meg (Martorell - Habicht 1986), egy tanulmány

${ }^{1}$ Daniel LaFave \& Duncan Thomas, 2017. „Height and cognition at work: Labor market productivity in a low income setting," Economics \& Human Biology, 25: 52-64. DOI: 10.3386/w22290. https://www. nber.org/papers/w22290.

${ }^{2}$ Debreceni Egyetem, Humán Tudományok Doktori Iskola, Szociológia és Társadalompolitika Doktori Program. 


\section{OLVASS FELESLEGESET!}

(Case - Paxson 2008) kiemeli, hogy a magasságra a fentieken túl az egyéb kora gyermekkori tapasztalatok is hatnak, illetve már a méhen belüli hatások is meghatározóvá válhatnak a magasság tekintetében; ilyen például a terhesség alatti dohányzás.

A megszületést követő három év jelentősen befolyásolja a felnőttkori magasságot, ez főként a gyermekkorban leggyakrabban előforduló gyomor-bélrendszeri, valamint felsőlégúti betegségek gyakoriságától függ, mivel ezek komoly akadályt jelenthetnek a növekedésben. Szintén alapvető fontossággal bír a kora gyermekkori táplálkozás, hiszen a fejlődés ebben a periódusban a leggyorsabb, és ilyenkor a legnagyobb a szervezet tápanyagigénye, ezért a megfelelő és kiegyensúlyozott táplálkozásnak bizony kiemelt szerepe van a későbbi testmagasság elérésében. Ezek természetesen szorosan összefüggenek az iskolaéretté válással (Case et al. 2009), a kognitív (Case - Paxson 2008) és nem-kognitív képességekkel (mint pl. az ambíció és a magabiztosság) (Persico et al. 2004). Továbbá az is igaz, hogy a magasság egy része genetikailag kódolt, ami miatt szinte bizonyosan összefügg a családi háttérrel, akár a generációkon átívelő családi „befektetésekkel”, azaz hogy milyen elvek alapján és milyen körülmények között nő fel a gyermek, és ezek a hagyományok, szokások hogyan öröklődnek tovább (pl. fontos-e az anya számára a terhesség alatti egészségmegőrzés, a megszületett gyermek megfelelő táplálása, immunizálása, van-e megfelelő háttér mindezek biztosítására).

Az alacsony jövedelműek munkaerőpiacán a magasságot a munkaadó az erő jelének tekinti, amihez a magasabb teljesítőképességet társítja (Sohn 2014, Yamamura - Smyth - Zhang 2015). De úgy is lehet érvelni, hogy mivel a dolgozók maguk választják ki azokat a munkahelyeket, ahol képességeiket jutalmazzák, ezért gyakran a magasabb, erősebb dolgozók elsősorban ezt a kiemelt juttatást veszik alapul, noha ők is rendelkezhetnek jobb kognitív képességekkel, és azoknak megfelelő pozícióban is el tudnának helyezkedni, nélkülözve ezzel természetesen a magasságért járó jutalmat (Vogl 2014).

\section{A tanulmány elméleti keretrendszere}

Igaz, hogy a különböző emberi tőkék hátterében a korai gyermekkor behatásai állnak, amelyet a szülői döntések határoznak meg, de az emberi tőke fejlődése és a képességek megszerzése is folytatódik az iskolai évek alatt, majd az első munkaerőpiaci tapasztalatok által, ami leginkább a továbbtanulásra és a képességfejlesztésre vonatkozó befektetésekről hozott döntésekben nyilvánul meg. Amikor az illető szembesül a több szektort, és gyakran a bizonytalan jövedelmú foglalkozásokat jelentő munkaerőpiaccal, akkor azt is érzékeli, hogy a továbbtanulás anyagi megszorításokkal jár, a várakozás egy jobb állásra esetleg elmulasztott munkalehetőségeket jelent. Továbbá, amikor az egyén választ a bérmunka és a jobbára informális jövedelmet jelentő önfoglalkoztatás között, akkor ez sem csupán a pillanatnyi előny 


\section{OLVASS FELESLEGESET!}

alapján történik, hanem folyománya az emberi tőke korábbi felhalmozási folyamatának, mint ahogy felnőttként is különféleképpen törődhetünk egészségi állapotunkkal, fejleszthetjük értelmi képességeinket, s tesszük mindezt gyakran az általuk választott ágazat és foglalkozás szempontjait is figyelembe véve.

Ahhoz, hogy szét lehessen választani azt, hogy mennyiben hatott a felnőttként elért magasságra a koragyerekkori egészségi állapot és a táplálkozási környezet, a családi háttér, majd az egyén által választott munka jellege és az ágazat, longitudinális vizsgálat szükséges, ami követi a munkaerőpiaci helyzet változásait (ágazat és foglalkozás, formális és informális jövedelmek), valamint a humán tőkébe történő beruházások alakulását.

\section{A kutatás}

A WISE egy nagyszabású, longitudinális kutatás, amelyet az indonéziai Jáva szigetén végeztek. A 2001 végén végzett lakosság-reprezentatív felmérést követően, a Purworejo tartományban élőkkel négyhavonta interjúkat készítettek 2002 és 2005 között. A hosszú távú nyomon követésre a kezdeti felmérést követőn 5 és 7 évvel később került sor, 2007-ben és 2009-ben. Mivel az elemzés az egyének követésére támaszkodik, így az idő múlásával elkerülhetetlen, hogy szelektív lemorzsolódásra ne kerüljön sor, de a WISE során rendkívül alacsony volt a lemorzsolódás, a 2002-es alapkutatás háztartásai közül 94\%-ot kérdeztek meg újra, 7 évvel később. A vizsgálatban 5304 férfi vett részt, 25-65 év közöttiek, akiknek ismert volt a jövedelme; összességében a panel több mint 38000 személyi megfigyelést foglalt magában.

\section{A jövedelem és a munkahely jellemzőinek mérése}

A WISE-kutatás során a háztartások minden 15 év feletti tagjától részletes információkat kértek a munkahelyi státuszról, a munkáltatóról és a foglalkozásról, a munkaidőről, a munka jellegéről (feladatkörök) és a fizetésről. A bérmunkából származó óránkénti jövedelmet a megelőző négy hónapban végzett munkából származó teljes jövedelem és az ugyanazon időszakban ledolgozott munkaórák hányadosaként számolták ki. Hasonlóképpen az egyéni vállalkozók órabére az előző négy hónap nettó nyeresége, és az ez idő alatt ledolgozott munkaórák aránya alapján lett kiszámolva. A WISE során alkalmazott négy hónapos felmérési hullámokat úgy választották meg, hogy azok egybeessenek a rizstermesztési ciklusokkal, ami azon a területen a domináns növény.

Az eredmények azt tükrözik, hogy azok, akik soha nem váltanak ágazatot, azokhoz képest, akik folyamatosan változtatnak, kevesebbet kerestek a bérmunka során, és többet, amikor egyéni vállalkozóként dolgoztak. 


\section{OLVASS FELESLEGESET!}

\section{A magasság, az értelmi képesség és az egyéb jellemzők mérése}

A háztartások minden tagjának magasságát mindegyik felmérési ciklus során megmérték. A felnőttek termete az időskor eléréséig viszonylag állandó, utána azonban zsugorodnak. E torzítás kiszűrése érdekében a mért magasságok átlagát használták. A mintába bekerült férfiak átlagos magassága 161,6 cm volt. Azok, akik kizárólag a bérágazatban dolgoznak, az átlaghoz képest magasabbak (163,7 cm); akik kizárólag önálló vállalkozók, azok alacsonyabbak voltak (160,5 cm); a mindkét szektorban dolgozók pedig a két érték közé estek $(161,4$ cm). (A mintába egyébként azért kizárólag férfiak kerültek be, mivel az indonéz munkaadók csak férfi munkavállalók esetében jutalmazzák a magasságot.)

A kutatás során az értelmi képességek méréséhez három különböző eszközt alkalmaztak. Az egyik ilyen mérőeszköz a Raven-féle Színes Progresszív Mátrixmintázat teszt, ami az intelligenciát jelzi (Raven 2000). A WISE során a Raven-teszt különböző részeit háromszor mutatták meg a 15 éves és annál idősebb válaszadóknak; és mivel a teljesítmény valószínűleg nem változik a felnőttkorban, ezért a modellek értékelése során az átlageredmények kerültek használatra.

A másik módszer a Fülöp-Szigeteki Nemzeti Intelligencia Teszt adaptálásai, a fluid intelligencia felmérésére. A Raven-teszthez hasonlóan ez is nonverbális, nem igényel írástudást vagy számolást; a mindennapi élet tárgyait és tevékenységeit használja a logikus gondolkodás mérésére.

A harmadik módszer során a memória minőségét értékelték egy szó-visszaemlékező teszttel, amely során minden válaszadónak felolvasnak 10 hétköznapi indonéz szót. A válaszadót megkérték, hogy tetszőleges sorrendben azonnal ismételje meg a szavakat; a segítség nélkül azonnal felidézett szavak száma az azonnali (rövid távú) visszaemlékezés. A felmérés az egészségi állapot kérdéseivel folytatódott, amely kb. öt percet vett igénybe, majd ismét felkérték a válaszadót, hogy idézzen vissza minél több szót a listából. A visszaidézett szavak száma a késleltetett (hosszú távú) visszaemlékezés. A munkamemória fontos szerepet játszik az érvelésben és a döntéshozatalban, ezért potenciálisan kapcsolódhat a munkaerőpiaci sikerekhez.

Mindhárom kognitív értékelés esetében azok átlaga volt a legmagasabb, akik életpályájuk során végig bérmunkásként dolgoztak, és azok között volt a legalacsonyabb, akik mindig egyéni vállalkozók voltak.

Az egyének által elért magasságok mérése mellett a felmérés több kiegészítő adatot is tartalmaz az egészségi állapotra vonatkozóan, amelyek potenciálisan kapcsolódhatnak a munkaerőpiaci termelékenységhez. Az egyik a testtömeg-index (BMI - a testsúly osztva a testmagasság négyzetével), ami a táplálkozási státusz mutatója. A magasságtól eltérően, ez az érték az életciklus során változik. A magasabb BMI-érték valószínűleg a fizikai erő és a kitartás mutatója, amelyet nagyra értékelnek a munkaadók a munkaerőpiacon. Az egészségi állapotra vonatkozóan vizsgálták azt is, hogy az illető képes-e egy km távolságot lefutni, akármilyen nehézség (idő előt- 


\section{OLVASS FELESLEGESET!}

ti kifáradás, fájdalom, légzési nehezítettség) nélkül; mivel azt feltételezték, hogy az ezzel felmért fizikai állapot egyenesen aránylik az erővel és a kitartással, amelyek szintén értékelendő tulajdonságok a munkaadók számára. A WISE továbbá vizsgálta a nyugalmi vérnyomásértékeket is, mivel a kezeletlen magas vérnyomás a cardiovascularis betegségek egyik magas rizikófaktora, illetve egyben prediktora is; és ez szintén hatással van a munkaerőpiaci teljesítőképességre.

\section{A felmérés eredményei}

Összességében a magasabb férfiak szignifikánsan jobb pontokat értek el a kognitív értékelés minden tekintetében, s az 1. ábrán az is látható, hogy a magasság és az órabér erősen összefügg.

1. ábra. Az órabér és a testmagasság összefüggése
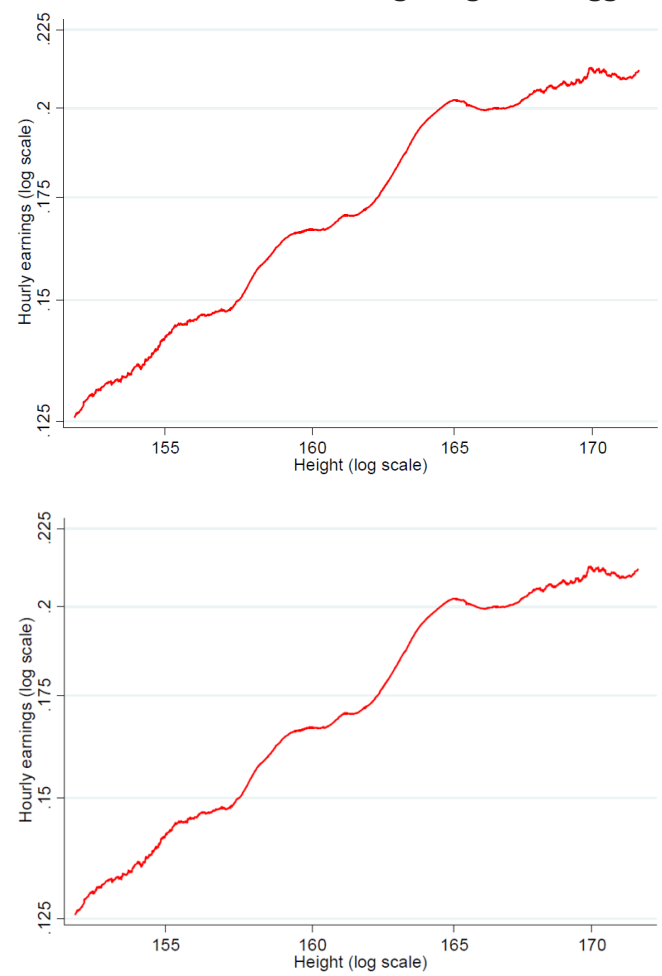

Forrás: Daniel LaFave - Duncan Thomas 2016: 24

Megjegyzés: A függőleges tengely az órabér, a vízszintes tengely a magasság logaritmusát mutatja. 


\section{OLVASS FELESLEGESET!}

Az emberi tőke hatását (az egyén által elért legmagasabb iskolai végzettség megszerzéséhez szükséges évek száma) az órabér és a magasság közötti összefüggés, az értelmi képességek és az egészségi állapot, továbbá számos egyéb, a munkaerőpiaci szakirodalomból ismert tényező (jövedelem-órabér, havi átlagkereset; termelőképesség, életkor, iskolázottság) kontrollja után vizsgálták; de néhány modell magába foglalta a legfontosabb egészségi állapotra vonatkozó mérőszámokat is, mint pl. a testtömeg-index, az $1 \mathrm{~km}$ távolság lefutását akadályozó tényezők, illetve két mért vérnyomásérték.

Megállapították továbbá, hogy a kor és az eltelt idő függvényében a magasabb egyének egyre többet keresnek; átlagosan 1\%-os magasságnövekedés 3,6\%-os órabér-emelkedést jelent. Azt is bemutatták, hogy mind a Raven-teszt, mind pedig a fluid intelligencia növeli az órabért.

Összefoglalva tehát az iskolázottság és a kognitív képességek megmagyarázzák az órabér és a magasság közötti összefüggés nagy részét, de a magasságnak ezen hatások kiszürése után is szignifikáns maradt a hatása. Ugyanakkor nincs különbség a magasság hatásának erejében, attól függően, hogy az adott egyén munkabért kap vagy egyéni vállalkozó.

A foglalkozás választása bizonyítottan függ az iskolai végzettségtől, a kognitív képességektől és a magasságtól. Azok az összefüggések, amit a foglalkozások közötti válogatás és a magasság, továbbá a kognitív készségek és a jövedelmek között találtak Mexikóban (Vogl 2014), teljes mértékben érvényesültek az indonéz férfiak körében végzett vizsgálatok eredményeiben is.

\section{Összegzés}

Ebben a tanulmányban egy igen érdekes és újszerú vizsgálat került bemutatásra arra vonatkozóan, hogy az indonéz vidékeken a magasság és az emberi tőke több dimenziója (az oktatásban elért eredmény, a kognitív képességek különböző jellemzői, az egészségi állapot egyes mutatói) is előnyt jelent a férfiak munkaerőpiacán. A humán tőkét meghatározó tényezők vizsgálatát követően az az érdekes eredmény született, hogy a magasabb férfiak magasabb órabért kapnak mind a bérszektorban, mind pedig egyéni vállalkozóként. A magasság előrejelzője lehet annak, hogy az indonéz férfiak milyen foglalkozást választanak, és a magasság egyben előnyt is jelent a munkaerőpiacon, ellentétben a fejlettebb országokkal, ahol a magasság munkaerőpiaci hatása jóval kisebb jelentőségű (Case - Paxson 2008). 


\section{OLVASS FELESLEGESET!}

\section{Irodalom}

Case, A. - Paxson, C. (2008): Height, health, and cognitive function at older ages. American Economic Review: Papers and Proceedings, 98(2): 463-467

Case, A. - Paxson, C. (2008): Stature and status: Height, ability, and labor market outcomes. The Journal of Political Economy, 116(3): 499

Case, A. - Paxson, C. - Islam, M. (2009): Making sense of the labor market height premium: Evidence from the British household panel survey. Economics Letters, 102(3): 174-176

Fogel, R. W. (2012): Explaining Long-term Trends in Health and Longevity. Cambridge, Cambridge University Press.

Guthrie, G. M. - Tayag, A. H. - Jacobs, P. J. (1977): The Philippine nonverbal intelligence test. The Journal of Social Psychology, 102(1): 3-11

Raven, J. (2000): The Raven's progressive matrices: Change and stability over culture and time. Cognitive Psychology, 41: 1-48

Sohn, K. (2015): The height premium in Indonesia. Economics and Human Biology, 16: $1-15$

Vogl, T. (2014): Height, skills, and labor market outcomes in Mexico. Journal of Development Economics. 107: 84-96 http://ipl.econ.duke.edu/dthomas/WISE/ index.html (utolsó letöltés: 2020. 03. 07.) 